\title{
DETECTION, ISOLATION, AND PRELIMINARY CHARACTERIZATION OF BACTERIA CONTAMINATING PLANT TISSUE CULTURES
}

\author{
${ }^{1}$ Monika Kałużna, ${ }^{1}$ Artur Mikiciński, ${ }^{1}$ Piotr Sobiczewski, ${ }^{1}$ Marta Zawadzka, \\ ${ }^{2}$ Elżbieta Zenkteler, ${ }^{1}$ Teresa Orlikowska \\ ${ }^{1}$ Research Institute of Horticulture, Konstytucji 3 Maja 1/3, 96-100 Skierniewice, Poland \\ ${ }^{2}$ Adam Mickiewicz University of Poznań, Biology Department, Umultowska 89, 61-614 Poznań, Poland \\ e-mail: Teresa.Orlikowska@inhort.pl
}

Received: 25.01.2013

\begin{abstract}
In order to limit the contamination problem in plant tissue cultures experiments on selection of media suitable for detection and isolation of bacteria contaminating plant tissue explants, and preliminary characterization of isolates were made. In the first experiment aiming at detection of bacteria in plant explants four strains representing genera most often occurring at our survey of plant tissue cultures, and earlier isolated and identified (Bacillus, Methylobacterium, Pseudomonas and Xanthomonas) were streaked on five bacteriological media (NA, King B, K, R2A and 523) and on the medium used for plant culture initiation $-1 / 2 \mathrm{MS}$ with milk albumin (IM). All strains grew on all media but on K and IM at the slowest rate and on 523 medium at the fastest. The IM medium proved to be useful for immediate bacteria detection at the initial stage of culture. In the second experiment, aiming at characterization of isolates on the basis of colony growth and morphology 14 strains (Agrobacterium, Bacillus, Curtobacterium, Flavobacterium, Lactobacillus, Methylobacterium - 2 strains Mycobacterium, Paenibacillus, Plantibacterium, Pseudomonas, Stenotrophomonas, Xanthomonas, and species Serratia marcescens) were streaked on five microbiological media: KB, NBY, YDC, YNA and YPGA. All strains grew on all those media but at different rates. The only exception was the strain of Lactobacillus spp., which did not grow on King B medium. This medium allowed the detection of such characteristic traits as fluorescence (Pseudomonas) and secretion of inclusions (Stenotrophomonas). The third experiment was focussed on assessment of the sensitivity of detection of specific bacteria in pure cultures and in plant tissue cultures using standard PCR and BIO-PCR techniques with genus specific primers and 2 methods of DNA isolation. Results showed that the use of Genomic Mini kit enabled an increase of the sensitivity by 100 times as compared to extraction of DNA by boiling. Moreover, the application of BIO-PCR increased sensitivity of detection from $10^{2}$ to $10^{5}$ times over the standard PCR. If looking for unknown cultivable bacteria more effective
\end{abstract}

detection seems to be use of microbiological method enabling detection on bacteriological media single cells in the fragments of explants or in wash liquids, in which fragmented explants were shaken.

Key words: bacterial contamination, plant tissue culture, bacteria detection, PCR, BIO-PCR

\section{INTRODUCTION}

Bacterial contaminations are a serious problem in plant in vitro cultures, both in commercial plant micropropagation, by making difficult culture initiation, reducing efficiency of multiplication and rooting of shoots, as well as in research laboratories, where contamination can be the causal agent of false results in physiological experiments $[1,2,3]$. The diversity and abundance of genera and species of exo- and endobiotic bacteria accompanying donor plants $[4,5]$ is a major challenge in the sterilization of initial explants, a quick detection of bacteria in the first in vitro passages and a minimization of their adverse effect on shoot multiplication and rooting efficiency. In most cases, bacteria are introduced to the cultures together with initial explants.

In practice, initial explants are only surface sterilized, and thus internally living microorganisms are introduced to in vitro cultures. If symptoms of bacteria colonizing plant tissues appeared within a short time, the contaminated explants should be immediately removed. In case when bacterial growth is very slow or temporarily retarded in plant culture conditions, they remain in a cryptic state and may appear only when the 
culture conditions will drastically change, for example after delayed subculture, increase of temperature, change of medium composition or due to other factors [6]. It is therefore important to use appropriate methods for quick bacteria detection and removal of contaminated cultures before microorganisms' spreading. Our large survey of plant tissue cultures originating from eight laboratories in Poland resulted in obtaining 104 isolates of bacteria, which were assigned by phenotypic tests and $16 \mathrm{~S}$ rDNA fragments sequencing to 29 genera (data not published).

The aim of present studies was to determine which media are suitable in detecting bacteria inhabiting plant explants. The next task was to assess usefulness of selected media for preliminary characterization of isolated bacteria. The third task was to find a way to identify taxa with genus specific primers in possible minimal population of bacteria, using two PCR techniques and two methods of DNA isolation.

\section{MATERIALS AND METHODS}

In the present study, isolates obtained from different plant tissue cultures, identified to the genera , were used.

Evaluation of media enabling detection, isolation and preliminary characterization of bacteria. In this experiment, which aimed at selecting medium suitable for detection and isolation of bacteria from initial explants, 4 strains of bacteria: 87 (Bacillus spp. isolated from Phalenopsis), E (Pseudomonas putida from Rubus ideaus), 81b (Methylobacteriumlusitanum from Sambucus nigra), and 78 (Xanthomonas from Sambucus nigra) were streaked on six media: King B (KB), Nutrient Agar (NA) + 1\% sucrose, $\mathrm{K}$ [7], R2A [8], 523 [9] and on plant tissue initiation medium (IM), containing 1/2 Murashige and Skoog inorganic salts [10], vitamins of WPM medium [11], $100 \mathrm{mg} \mathrm{l}^{-1}$ inositol, $0.5 \mathrm{mgl}^{-1}$ benzyladenine, $30 \mathrm{~g} \mathrm{l}^{-1}$ sucrose, $250 \mathrm{mg} \mathrm{l}^{-1}$ milk albumin and $6.6 \mathrm{~g} \mathrm{l}^{-1}$ Plant Agar (Duchefa). Growth and morphology of bacterial colonies were evaluated every $24 \mathrm{~h}$ for 7 days and photographed.

Evaluation of media enabling bacteria characterization. In the experiment aimed at selection of medium enabling preliminary characterization of isolated bacteria, 14 strains, representing the genera most often found in surveyed plant tissue cultures: Agrobacterium, Plantibacterium, and Xanthomonas (each from Sambucus nigra), Bacillus (from Phalenopsis), Flavobacterium (from Daucus carota), Lactobacillus (from Hosta), Methylobacterium (2 strains), Curtobacterium, Mycobacterium, Paenibacillus, Pseudomonas, Stenotrophomonas (each from Rubus ideaus) and Serratia marcescens (from Alocasia), were streaked on the following media: King B (KB), Nutrient
Broth-Yeast Extract (NBY), Yeast Dextrose Chalk Agar (YDC), Nutrient Agar supplemented with 0.5\% yeast extract (YNA), and Yeast Peptone Glucose Agar (YPGA) [12, 13]. Observations of colony morphology were made every $24 \mathrm{~h}$ for 7 days. Time of colonies appearance, their size, and morphology were recorded. The KB, NA, NBY, YDC, YNA and YPGA are known as universal bacteriological media but R2A and 523 (in both low amount of organic nitrogen, 523 contains sucrose) are used for isolation of bacteria from in vitro plant cultures. $\mathrm{K}$ medium has been recommended for isolation of Methylobacteriaceae (without organic nitrogen and with methanol as the only source of carbon) and IM is usually used as the initial medium for introduction of plant explants to in vitro cultures.

Sensitivity of bacteria detection in pure cultures using PCR with genus specific primers. This model experiment aimed at possibility of detection the minimal number of bacteria in a sample. Bacterial suspensions of three strains were prepared by washing off bacterial colonies with sterile water. Strain 87 (Bacillus) was cultivated on NA $+1 \%$ sucrose, isolate $\mathrm{E}$ (Pseudomonas) and isolate 81b (Methylobacterium) on KB medium. The initial concentration of suspension for strain 87 was $2 \times 10^{7}$, for $81 \mathrm{~b}-2 \times 10^{6}$, and for strain $\mathrm{E}-5 \times 10^{7} \mathrm{cfu} \mathrm{ml}^{-1}$. Each of them was then serially tenfold diluted to final concentration $10^{0} \mathrm{cfu} \mathrm{ml}^{-1}$. From each dilution, DNA was isolated by two methods. 1/ One $\mathrm{ml}$ of each bacterial suspension was boiled for $10 \mathrm{~min}$, cooled on ice and centrifuged at $14000 \mathrm{rpm}$; one $\mu$ l of supernatant was used in standard PCR reactions. 2/ One $\mathrm{ml}$ of each bacterial suspension was centrifuged at $14000 \mathrm{rpm}$, re-suspended in $100 \mu \mathrm{TE}$ buffer and DNA was isolated using Genomic Mini kit for DNA extraction according to manufacturer's instruction (A\&A Biotechnology). One $\mu$ l of DNA (after isolation from each bacterial dilution) was used in standard PCR reactions.

Additionally, to compare detection sensitivity of standard PCR with BIO-PCR (pre-incubation followed by amplification) $100 \mu \mathrm{l}$ of each dilution of bacterial suspension of each isolate was streaked on appropriate medium, as described above. The plates were incubated at $26^{\circ} \mathrm{C}$ for up to 5 days. At respective time, single colonies were counted and then washed off with $3 \mathrm{ml}$ of sterile water; $2 \mathrm{ml}$ of the suspension were used for DNA isolation with the same two methods as described above.

To assess the sensitivity of bacteria detection using standard PCR and BIO-PCR and two different DNA isolation methods the following primer pairs were used: for Bacillus - Bac-200 and Bac-470 [14], for Methylobacterium - Met2F and Met2R [15] and for Pseudomonas - primers Ps-for and Ps-rev [16]. Amplifications were performed in $15 \mu$ of a reaction solution containing: $2 \mu \mathrm{l}$ of DNA, $0.4 \mathrm{U}$ polymerase GoTaq DNA (Promega Corp. USA), 1x buffer GoTaq, 
$0.2 \mathrm{mM}$ of each DNTP and $1 \mu \mathrm{M}$ of primers. All amplification reactions were conducted according to the recommendation of the authors with only modification for Bacillus (lowering of annealing temperature by $8^{\circ} \mathrm{C}$ ). PCRs were carried out in T3000 Biometra thermal cycler. PCR products were separated on a $1.5 \%$ agarose gel with $0.5 \mathrm{TBE}$ buffer and visualized by staining with ethidium bromide $\left(0.5 \mathrm{mg}^{-1}\right)$.

Sensitivity of bacteria detection in in vitro plant explants artificially contaminated with bacteria. The shoots for the experiment were harvested from the stock cultures „free of cultivable bacteria”. The stocks were initiated from microshoots indexed two times, in two subsequent subcultures, for the presence of contamination by placing the basal parts of shoots on two bacteriological media: Nutrient Agar and 523 medium. The shoots, from which bacteria did not grow in both subcultures, were considered as free of cultivable bacteria. The single microshoots were transferred to jars containing perlite saturated with liquid rooting medium appropriate for each plant species and $100 \mu \mathrm{l}$ of $24 \mathrm{~h}$ bacterial suspension was injected in the centre of a jar immediately after shoot transfer. Microshoots of Gerbera $\mathrm{x}$ hybrida 'Kormoran' were contaminated with strain 87 of Bacillus spp., Anthurium x andreanum 'Bolero' contaminated with strain E of Pseudomonas putida and Sambucus nigra contaminated with strain of $81 \mathrm{~b}$ of $\mathrm{Me}$ thylobacterium lusitanum. After 4 weeks, the roots were cut off, and the shoots transferred to propagation agar medium appropriate for each plant species. Explants showing symptoms of bacteria presence in the form of visible leakage into agar medium or halo around shoot base were aseptically divided into three segments: I - at the base, II - middle part and, III - top. Bulk samples of $100 \mathrm{mg}$ of fragmented tissues from several explants of the same segment of each plant species were shaken in $3 \mathrm{ml}$ of PBS buffer $\left(0.27 \% \mathrm{Na}_{2} \mathrm{HPO}_{4}, 0.04 \% \mathrm{NaH}_{2} \mathrm{PO}_{4}\right.$, $0.8 \% \mathrm{NaCl}$ ) at $26^{\circ} \mathrm{C}$ for $1 \mathrm{~h}$. Two $\mathrm{ml}$ of obtained liquids were used for isolation of DNA by boiling or using Genomic Mini kit as described above.

Additionally, to compare detection sensitivity by standard PCR and BIO-PCR (bacteria pre-incubation followed by DNA isolation and amplification) $100 \mu \mathrm{l}$ of liquid obtained from each plant segment was placed on appropriate medium for each isolate, as described above. After incubation at $26^{\circ} \mathrm{C}$ for up to 5 days, the colonies were counted and then washed off with $3 \mathrm{ml}$ of sterile water; $2 \mathrm{ml}$ of the resulting suspension were used for DNA isolation using the same two methods as described above. Detection of bacterial DNA in plant material was conducted using PCR with the genus specific primers and according to conditions described above.

Bacteria detection in apparently healthy in vitro plant explants. Total DNA was individually isolated by Qiagen Plant Mini kit from bulk samples of in vitro shoots of Chrysanthemum x hybrida 'Ludo', Kalanchoë blossfeldiana 'Debbie', Gerbera x hybrida 'Kormoran' and Sorbus aucuparia, which never have shown contamination symptoms at visual inspections. DNA was used for detection of possible bacterial contamination using standard PCR. Universal primers fD1/rP2 for 16S rDNA of bacteria [17] and genus specific primers for Bacillus, Methylobacterium and Pseudomonas (as listed above) were used. The following PCR conditions for primers fD1/rP2 were applied: $94^{\circ} \mathrm{C} 4 \mathrm{~min}$., 35 cycles: $45 \mathrm{~s}$ at $95^{\circ} \mathrm{C}, 45 \mathrm{~s}$ at $55^{\circ} \mathrm{C}, 90 \mathrm{~s} 72^{\circ} \mathrm{C}$ and $10 \mathrm{~min}$ at $72^{\circ} \mathrm{C} .25 \mu \mathrm{l}$ of reaction mixture contained: $25 \mathrm{ng}$ DNA, $0.5 \mathrm{U}$ Tag polymerase (Fermentas), $0.5 \mu \mathrm{M}$ of each primer, $50 \mu \mathrm{M}$ each of dNTP and $1.5 \mathrm{mM} \mathrm{MgCl} 2$. For genus specific primers, the same PCR conditions were applied, as described above.

\section{RESULTS}

Growth and colony morphology of bacteria on different media., The most efficient among six media tested in terms of rate of bacteria growth was medium 523. The IM medium proved to be useful for growth three of the four bacterial strains, although at the slowest rate (colonies were visible 3 - 5 days later in comparison to other media used). However, single colonies of Bacillus spp. have not been observed on this medium within 7 days (Table 1; Figs 1-4).

All the five media used allowed growth of 14 bacterial strains representing different genera. NBY was the most favourable medium for growth of $\mathrm{Ba}$ cillus, Curtobacterium, Lactobacillus, Methylobacterium, Plantibacterium, Xanthomonas and Serratia marcescens strains. The King B medium appeared to be most appropriate for Stenotrophomonas because of secretion of characteristic inclusions and for Pseudomonas because of fluorescent pigment production (Table 2). Lactobacillus growth was possible under mineral oil on four media but not on KB.

Sensitivity of bacteria detection/identification in pure cultures using PCR with genus-specific primers. The sensitivity depended on DNA isolation method (boiling or Genomic Mini kit) and applying pre-incubation of bacteria on bacteriological medium (BIO-PCR). The use of Genomic Mini kit for DNA extraction let to increase sensitivity 100 times for $\mathrm{Me}$ thylobacterium and 1000 times for Bacillus, as compared to extraction of DNA by boiling. Only the sensitivity of detection/identification of Pseudomonas isolate did not depend on the method of DNA isolation used. Application of BIO-PCR increased the sensitivity by $10^{2}$ to $10^{5}$ times over the standard PCR, independently on the method of DNA isolation used (Table 3, Figs 5-7).

Detection of bacteria using PCR with genus-specific primers in plant explants artificially contaminated. The analysis of bacteria presence in all three segments of Anthurium x andreanum 'Bolero', Gerbera 
x hybrida 'Kormoran' and Sambucus nigra explants, intentionally contaminated with bacteria, showed decrease in their number in the shoots going from bottom to top (Table 4). The highest differences between segments were found in Bacillus spp./Anthurium complex where in the top segments 125 times less bacteria was found than in a bottom part. However, in case of Pseudomonas putida/Gerbera there was only 8 times less bacteria in the top segments and in Methylobacterium lusitanum/ Sambucus only 3 times less than in a bottom segments, respectively.

Independently of the method of DNA extraction - Genomic Mini kit or boiling, plating of liquids after shaking of tissues in PBS buffer on bacteriological media (BIO-PCR) allowed detection/identification of one cell of Pseudomonas and Methylobacterium isolates.
Moreover, applying pre-incubation of bacteria increased the sensitivity by 100 to 1000 times in comparison to standard PCR (data not shown). However, in case of Bacillus strain the detection was possible only with pre-incubation.

Bacteria detection in apparently healthy in vitro plant explants using PCR with genus-specific and universal bacterial primers. None of specific DNA fragments of Pseudomonas, Bacillus, and Methylobacterium were detected in total DNA isolated using the Qiagen Plant Mini Kit from explants of Kalanchoë, Gerbera, Sorbus and Chrysanthemum that did not exhibit bacterial contamination. On the other hand, PCR analyses of plant DNA with primers fD1/rP2, universal for bacterial 16S rDNA, revealed the presence of bacterial DNA in each sample of plant explants.

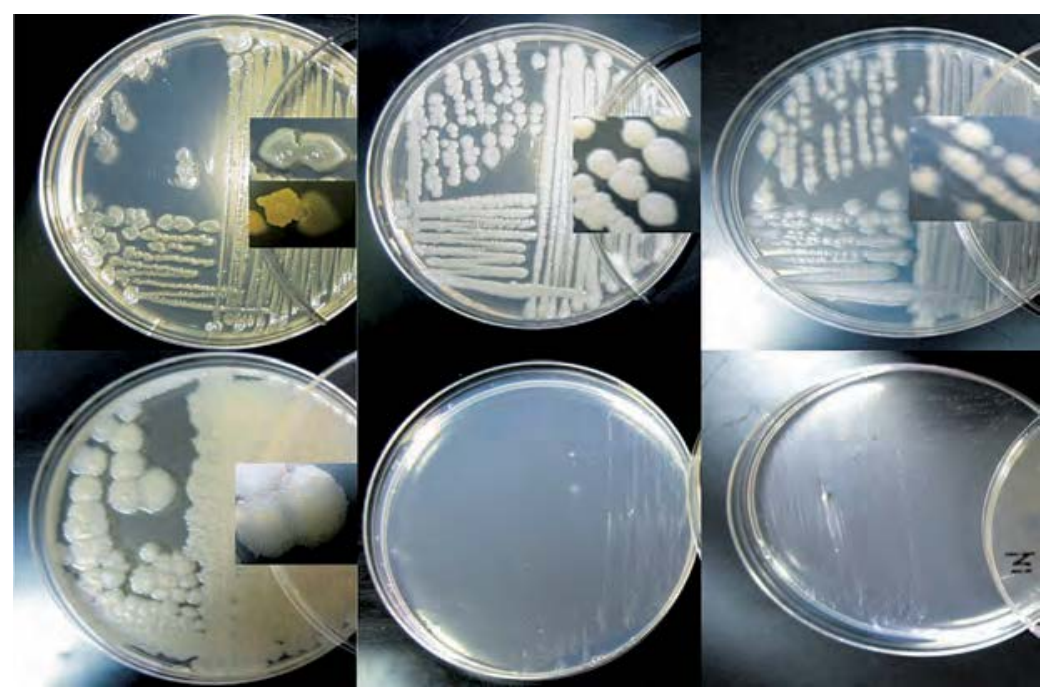

Fig. 1. The growth of Bacillus spp. (strain 87 isolated from shoot cultures of Phalenopsis) on 6 media after 48 h: a. KB, b. NA + 1\% sucrose, c. R2A, d. 523; after 120 h: e. K medium, f. IM (1/2 MS medium + 0.025\% milk albumine).

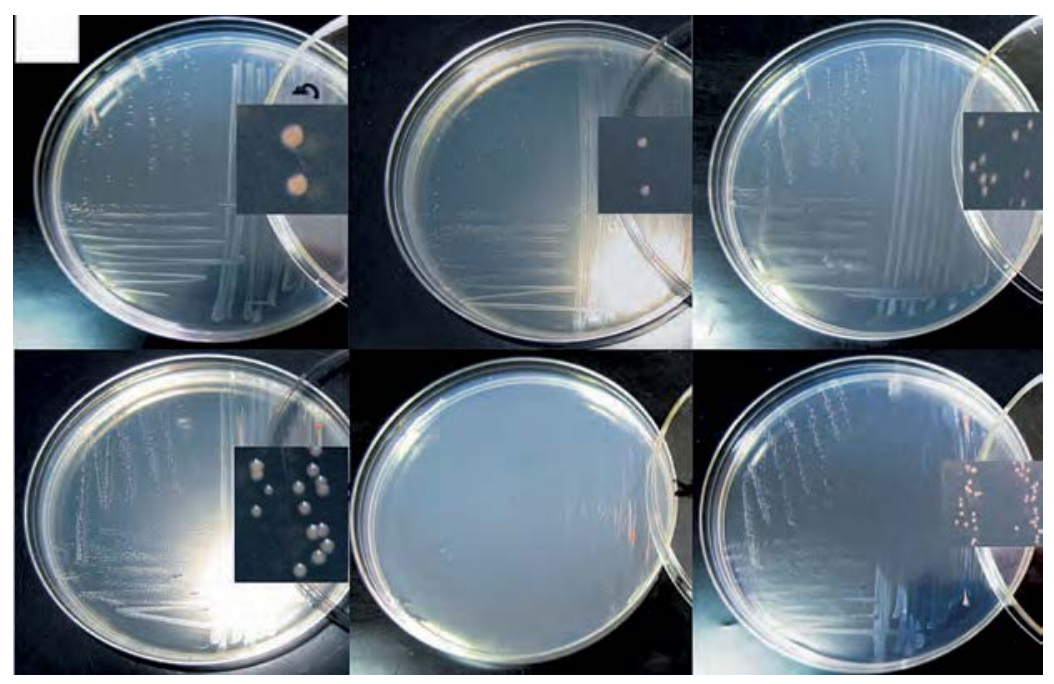

Fig. 2. The growth of Methylobacterium lusitanum (strain 81b isolated from shoot cultures of Sambucus nigra) on 6 media after 96 h: a. KB, b. NA + 1\% sucrose, c. R2A, d. 523; after 120 h: e. K medium, f. IM ( $1 \frac{2}{2}$ MS medium + 0.025\% milk albumine). 


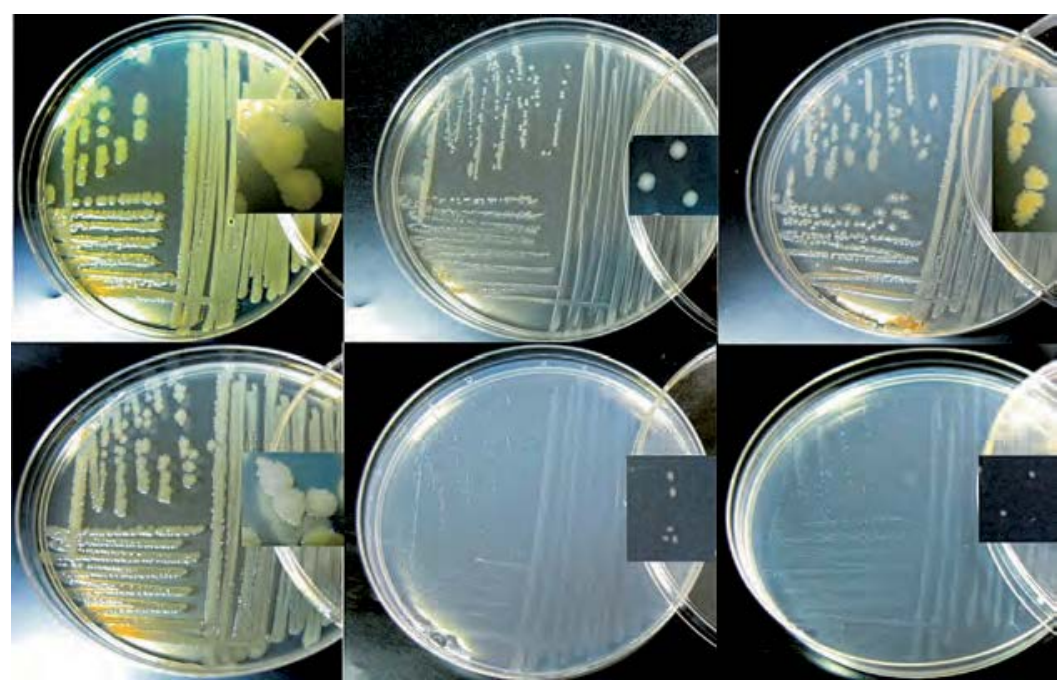

Fig. 3. The growth of Pseudomonas putida (strain E isolated from shoot cultures of Rubus ideaus) on 6 media after 48 h: a. KB, b. $\mathrm{NA}+1 \%$ sucrose., c. R2A, d. 523 ; e. after $72 \mathrm{~h}$ on K medium, f. after $96 \mathrm{~h}$ on IM ( $1 / 2 \mathrm{MS}$ medium $+0.025 \%$ milk albumine).

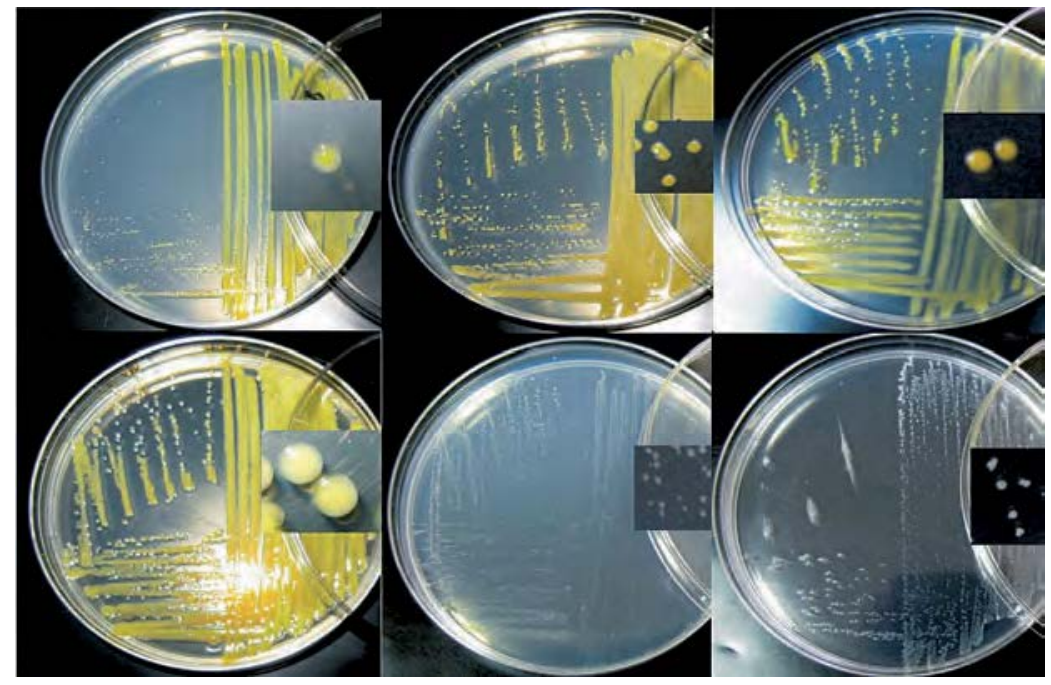

Fig. 4. The growth of Xanthomonas spp. (strain 78 isolated from shoot cultures of Sambucus nigra) on 6 media after 48 h: a. KB, b.

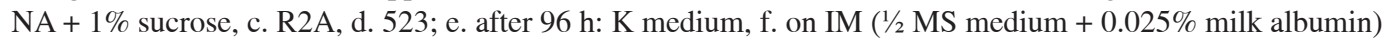

\section{DISCUSSION}

Our survey of bacteria contaminated plant tissue cultures originating from eight laboratories confirmed earlier reports about the presence of multitude of bacteria associated with plant tissue cultures $[4,5]$. The range of bacterial taxa varies depending on the geographical zone, plant species, conditions in which donor plants grew and on the source of contamination [18]. Nevertheless, some bacteria, such as those belonging to genera: Bacillus, Pseudomonas, Methylobacterium, Corynebacterium, Staphylococcus, and Agrobacterium are ubiquitous.

Although disinfection of donor plant materials is always of special importance in the process of mi- cropropagation, usually contaminations are introduced with the initial explants. Bacteria live in the plant vessels, intercellular spaces but also inside plant cells [19], which is the reason of unsuccessfulness of surface sterilization. To overcome this problem initiation of in vitro cultures from as small explants (very short shoot tips or meristems) as possible and detection of cultivable bacteria presence in these small explants as early as possible, is recommended. For this purpose, a shaking of fragmented bases of explants in sterile water or PBS buffer and plating of obtained liquid on microbiological medium, as it was performed in our study, is advisable. It is most effective when bacteria can be detected already on/ in the initial medium, as IM, typical medium for plant culture initiation, with the addition of $0.025 \%$ of milk 
albumin, which, in our experiment, enabled detection at least strains of Methylobacterium, Pseudomonas and Xanthomonas. On this medium, colonies of Pseudomonas were visible after 3 days, Xanthomonas after 4 days, and Methylobacterium after 5 days. Only in case of $\mathrm{Ba}$ cillus strain single colonies were not observed after streaking on Initiation Medium until $7^{\text {th }}$ day but weak growth of bacteria only at first lines of streaking was visible. All microbiological media used enabled to observe growth of bacteria but for not all of them single colonies were present. K medium, recommended for Methylobacteriaceae [7] was not useful for our Methylobacterium strain. However, we can underline usefulness of the 523 medium [9], which stimulated growth of colonies of all strains used more than KB or NA media. Nevertheless, a lack of bacteria growth on the bacteriological media does not guarantee the absence of any bacteria in the su- rveyed tissue because some bacteria can be uncultivable permanently or temporarily. For example, Xanthomonas campestris pv. dieffenbachiae (anthurium pathogen) could persist in the latent stage in in vitro shoot explants remaining undetected for one year [20]. The bacteriological media used in our experiment were not relevant to complete characterization and identification of bacteria. The exception was King B, which enables visualization of two features - fluorescent pigment characteristic to most Pseudomonas species and secretion of inclusions characteristic to Stenotrophomonas. Although the color of bacterial colonies as the only feature, can be not used for bacteria identification, nevertheless pink color of colonies and their slow growth may suggest the presence of one of the Methylobacterium, claret color and very rapid growth - Serratia marcescens, and yellow colorXanthomonas or Flavobacterium.

Table 1

Morphology of bacterial colonies on different media

\begin{tabular}{|c|c|c|c|c|c|}
\hline KB & $\begin{array}{c}\mathrm{NA}+1 \% \\
\text { sucrose }\end{array}$ & R2A & 523 & $\mathbf{K}$ & $\begin{array}{c}\text { IM }(1 / 2 \text { MS })+ \\
0.025 \% \text { milk } \\
\text { albumin }\end{array}$ \\
\hline
\end{tabular}

Bacillus spp. (87 from Phalenopsis)

\begin{tabular}{|c|c|c|c|c|}
\hline $\begin{array}{l}* 24 \mathrm{~h}, 1-2 \mathrm{~mm} \\
\text { in diameter, light } \\
\text { beige, flat, irregular } \\
\text { shaped in the form of } \\
\text { elongated tear drops } \\
\text { (Fig. 1a) }\end{array}$ & $\begin{array}{l}24 \mathrm{~h}, 1-2 \mathrm{~mm}, \\
\text { gray-white, } \\
\text { flat ,circular, } \\
\text { irregular shaped } \\
\text { (Fig. 1b) }\end{array}$ & $\begin{array}{l}24 \mathrm{~h}, 1 \mathrm{~mm} \text {, gray- } \\
\text { white, elongated, flat, } \\
\text { matt, circular, irregular } \\
\text { shaped slightly jagged } \\
\text { edges (Fig. 1c) }\end{array}$ & $\begin{array}{l}24 \mathrm{~h}, 2-3 \mathrm{~mm} \text { creamy, } \\
\text { circular shaped with a } \\
\text { distinctive shiny hallo } \\
\text { around convex, flat } \\
\text { rough (Fig. 1d) }\end{array}$ & $\begin{array}{l}120 \mathrm{~h} \text { lack of single colonies, } \\
\text { growth only in the first line of } \\
\text { a smear (Fig. 1e and f) }\end{array}$ \\
\hline
\end{tabular}

Methylobacterium lusitanum (81b from Sambucus nigra)

\begin{tabular}{|c|c|c|c|c|c|}
\hline $\begin{array}{l}96 \mathrm{~h} 1 \mathrm{~mm} \text {, bright } \\
\text { pink, regular in shape, } \\
\text { round and slightly } \\
\text { convex with a full } \\
\text { edge (Fig. 2a) }\end{array}$ & $\begin{array}{l}96 \mathrm{~h}, 0.5 \mathrm{~mm} \text {, } \\
\text { small bright } \\
\text { pink, regular in } \\
\text { shape round and } \\
\text { slightly convex } \\
\text { with a full edge }\end{array}$ & $\begin{array}{l}96 \mathrm{~h}, 0.5-1 \mathrm{~mm} \text {, } \\
\text { bright pink, regular } \\
\text { in shape, round and } \\
\text { slightly convex with } \\
\text { a full edge (Fig. 2c) }\end{array}$ & $\begin{array}{l}96 \mathrm{~h}, 0.5-1 \mathrm{~mm} \text {, pink, } \\
\text { regular in shape, } \\
\text { round and slightly } \\
\text { convex with a full } \\
\text { edge (Fig. } 2 \mathrm{~d} \text { ) }\end{array}$ & $\begin{array}{l}120 \text { h lack of } \\
\text { single colonies } \\
\text { growth only } \\
\text { in the first } \\
\text { line of a smear } \\
\text { (Fig. 2e) }\end{array}$ & $\begin{array}{l}120 \mathrm{~h}, 0.2 \mathrm{~mm} \\
\text { pink, regular in } \\
\text { shape, round } \\
\text { and slightly } \\
\text { convex (Fig. 2f) }\end{array}$ \\
\hline
\end{tabular}

(Fig. 2b)

Pseudomonas putida (E from Rubus ideaus)

\begin{tabular}{|c|c|c|c|c|}
\hline $\begin{array}{l}24-48 \text { h, } 2 \mathrm{~mm} \text {, } \\
\text { yellow-green, shiny, } \\
\text { flat, round fluorescent } \\
\text { under UV light } \\
\text { (Fig. 3a) }\end{array}$ & $\begin{array}{l}24-48 \mathrm{~h}, 0.5 \mathrm{~mm} \text {, } \\
\text { circular, regular } \\
\text { in shape, shiny, } \\
\text { lightly convex } \\
\text { (Fig. 3b) }\end{array}$ & $\begin{array}{l}24-48 \mathrm{~h}, 1 \mathrm{~mm} \text {, } \\
\text { single, irregular, } \\
\text { tear-shape, more } \\
\text { intensive color } \\
\text { in the middle, little } \\
\text { frayed at the margins } \\
\text { (Fig } 3 \mathrm{c} \text { ) }\end{array}$ & $\begin{array}{l}24-48 \mathrm{~h}, 3-4 \mathrm{~mm} \text {, } \\
\text { candle-flame in } \\
\text { shape, creamy with } \\
\text { more intensive color } \\
\text { in the middle, little } \\
\text { frayed at the margins } \\
\text { (Fig } 3 \mathrm{~d})\end{array}$ & $\begin{array}{l}72-96 \text { h } 0.2 \mathrm{~mm} \text {, very small, } \\
\text { round, creamy, single, round } \\
\text { (Fig. 3e and f) }\end{array}$ \\
\hline
\end{tabular}

Xanthomonas spp. (78 from Sambucus nigra)

\begin{tabular}{|c|c|c|c|c|}
\hline $\begin{array}{l}48 \mathrm{~h}, 0.5-1 \mathrm{~mm} \\
\text { yellow, round, } \\
\text { in shape shiny, little } \\
\text { convex (Fig. 4a) }\end{array}$ & $\begin{array}{l}48 \mathrm{~h}, 0.5-1 \mathrm{~mm} \text {, } \\
\text { small, light } \\
\text { yellow, shiny, } \\
\text { regular in shape } \\
\text { (Fig. 4b) }\end{array}$ & $\begin{array}{l}48 \mathrm{~h}, 1-2 \mathrm{~mm} \text {, single, } \\
\text { yellow, shiny, circular, } \\
\text { regular in shape, little } \\
\text { convex (Fig. 4c) }\end{array}$ & $\begin{array}{l}48 \mathrm{~h}, 2-3 \mathrm{~mm} \text { bright } \\
\text { yellow, shiny, little } \\
\text { convex, regular in } \\
\text { shape (Fig. 4d) }\end{array}$ & $\begin{array}{l}96 \mathrm{~h}, 0.5 \mathrm{~mm} \text {, creamy } \\
\text { on } \mathrm{K} \text { and white on MS medium, } \\
\text { flat, regular in shape } \\
\text { (Fig. } 4 \mathrm{e} \text { and } \mathrm{f} \text { ) }\end{array}$ \\
\hline
\end{tabular}

*Given is time (h) and diameter of colonies (mm) when they were recognizable 
Table 2

Morphology of bacterial colonies on different microbiological media. The shadowed cells show the most appropriate medium.

\begin{tabular}{|c|c|c|c|c|}
\hline \multicolumn{5}{|c|}{ Morphology of bacterial colonies on microbiological media } \\
\hline KB & NBY & YDC & YNA & YPGA \\
\hline \multicolumn{5}{|c|}{ Agrobacterium tumefaciens ( 81afrom Sambucus nigra) } \\
\hline $\begin{array}{l}* 96 \mathrm{~h}, 0.1-0.2 \mathrm{~mm} \text {, white- } \\
\text { creamy, small, regular, shiny }\end{array}$ & $\begin{array}{l}96 \mathrm{~h}, 1 \mathrm{~mm} \text {, creamy } \\
\text { translucent, growth only in } \\
\text { the first line of streaking }\end{array}$ & $\begin{array}{l}96 \mathrm{~h}, 1 \mathrm{~mm} \text {, white- } \\
\text { creamy, luminescent }\end{array}$ & $\begin{array}{l}96 \mathrm{~h}, 1 \mathrm{~mm} \text {, creamy } \\
\text { translucent, growth only in } \\
\text { the first line of streaking }\end{array}$ & $\begin{array}{l}96 \mathrm{~h}, 1-1.5 \mathrm{~mm} \text {, white, } \\
\text { round shiny, }\end{array}$ \\
\hline \multicolumn{5}{|c|}{ Bacillus spp. (87 from Phalenopsis) } \\
\hline $\begin{array}{l}24 \mathrm{~h} \text {, light beige, flat, irregular } \\
\text { shaped in the form of } \\
\text { elongated tear drops, } 1-2 \mathrm{~mm}\end{array}$ & $\begin{array}{l}24 \mathrm{~h} \text {, white to } \\
\text { white-creamy; flocky, } \\
\text { tear-shape, } 2 \mathrm{~mm}\end{array}$ & $\begin{array}{l}24 \mathrm{~h} \text {, white to white- } \\
\text { creamy, flocky, tear- } \\
\text { shape, } 2 \mathrm{~mm}\end{array}$ & $\begin{array}{l}24 \mathrm{~h} \text {, white to } \\
\text { white-creamy, flocky, } \\
\text { tear-shape, } 2 \mathrm{~mm}\end{array}$ & $\begin{array}{l}24 \mathrm{~h} \text {, white to white- } \\
\text { creamy, flocky, } \\
\text { tear-shape, } 2 \mathrm{~mm}\end{array}$ \\
\hline
\end{tabular}

$96 \mathrm{~h}$, creamy, $0.6 \mathrm{~mm}$

$48 \mathrm{~h}$, yellow with darker in
the centre, flat, $0.4 \mathrm{~mm}$
the centre, flat, $0.4 \mathrm{~mm}$

No growth

No growth

$96 \mathrm{~h}$

\section{Curtobacterium spp. (38 from Rubus ideaus)
(3)}

\section{Flavobacterium spp. (4W from Daucus carota)}

$96 \mathrm{~h}$, dark yellow, $\quad 96 \mathrm{~h}$, pale yellow, flat, $96 \mathrm{~h}$, pale yellow, flat, flat, $0.4 \mathrm{~mm}$ $0.5 \mathrm{~mm} \quad 0.5 \mathrm{~mm}$

\section{$96 \mathrm{~h}, \mathrm{pa}$
$0.5 \mathrm{~mm}$
Hosta)}

\section{*Lactobacillus spp. (90 from Hosta)}

\begin{tabular}{l|lll}
$\begin{array}{l}96 \mathrm{~h}, \text { light creamy, } \\
\text { translucent, } 0.2 \mathrm{~mm}\end{array}$ & $\begin{array}{l}96 \mathrm{~h} \text {, light creamy, } \\
\text { translucent, } 0.2 \mathrm{~mm}\end{array}$ & $\begin{array}{l}96 \mathrm{~h} \text {, light creamy, } \\
\text { translucent, } 0.2 \mathrm{~mm}\end{array}$ & $\begin{array}{l}96 \mathrm{~h} \text {, light creamy, } \\
\text { translucent, } 0.2 \mathrm{~mm}\end{array}$
\end{tabular}

\section{Methylobacterium spp. (55 from Rubus ideaus)}

$96 \mathrm{~h}$, light pink, 0.6-0.7 mm

$96 \mathrm{~h}$, light pink, $1 \mathrm{~mm} \quad 96 \mathrm{~h}$, pink $0.3-0.5 \mathrm{~mm} \quad 168 \mathrm{~h}$, pink, $0.2 \mathrm{~mm}$

$168 \mathrm{~h}$, light pink, $0.6 \mathrm{~mm}$

\section{Methylobacterium spp. (B from Rubus ideaus)}

\begin{tabular}{|c|c|c|c|c|}
\hline $\begin{array}{l}96 \mathrm{~h} \text {, bright pink, regular in } \\
\text { shape, round and slightly } \\
\text { convex with a full edge, } 1 \mathrm{~mm}\end{array}$ & $\begin{array}{l}96 \mathrm{~h}, \text { pink, shiny, } \\
0.1-0.2 \mathrm{~mm}\end{array}$ & $\begin{array}{l}96 \mathrm{~h} \text {, light pink, shiny, } \\
0.1-0.2 \mathrm{~mm}\end{array}$ & $\begin{array}{l}96 \mathrm{~h}, \text { light pink, shiny, } \\
0.1-0.2 \mathrm{~mm}\end{array}$ & $\begin{array}{l}96 \mathrm{~h}, \text { pink, shiny, } \\
0.1-0.2 \mathrm{~mm}\end{array}$ \\
\hline
\end{tabular}
convex with a full edge, $1 \mathrm{~mm}$
$96 \mathrm{~h}$, pink, shiny,
$96 \mathrm{~h}$, light p
$0.1-0.2 \mathrm{~mm}$
$96 \mathrm{~h}$, light pin
$0.1-0.2 \mathrm{~mm}$
$0.1-0.2 \mathrm{~mm}$

$96 \mathrm{~h}$, yellow, convex, 2 $\mathrm{mm}$

\section{Mycobacterium spp. (39 from Rubus ideaus 0 \\ 96 h, creamy, \\ $96 \mathrm{~h}$, light yellow, \\ 96 h, creamy, 0.4-0.5 mm $0.4-0.5 \mathrm{~mm}$ $0.4-0.5 \mathrm{~mm}$}

96 h, creamy,

$96 \mathrm{~h}$, light yellow,

0.4-0.5 mm $0.4-0.5 \mathrm{~mm}$

Paenibacillus spp. (I from Rubus ideaus)

$48 \mathrm{~h}$, white-creamy, non regular- flocking, $0.1 \mathrm{~mm}$, $96 \mathrm{~h}-0.3 \mathrm{~mm}$

48 h, creamy-yellow, translucent, $0.4 \mathrm{~mm}$
$48 \mathrm{~h}$, white, non regular, translucent, $0.1 \mathrm{~mm}$, $96 \mathrm{~h}-0.3 \mathrm{~mm}$

$48 \mathrm{~h}$, white-creamy, $\quad 48 \mathrm{~h}$, white, $0.1 \mathrm{~mm} ; 96$
translucent, $0.1 \mathrm{~mm} ; \quad$ h- $0.3 \mathrm{~mm}$

$48 \mathrm{~h}$, white-creamy,
translucent, $0.1 \mathrm{~mm}$; $96 \mathrm{~h}-1 \mathrm{~mm}$
$96 \mathrm{~h}$, white-crème, translucent, $0.3 \mathrm{~mm}$

\section{Plantibacterium spp. (752 from Sambucus nigra)}

$48 \mathrm{~h}$, white to yellow, $\quad 96 \mathrm{~h}$, sunny yellow, $\quad 48 \mathrm{~h}$, lemon yellow, flat, $48 \mathrm{~h}$, white creamy, translucent, shiny, flat, shiny, $0.3 \mathrm{~mm}$, $0.4 \mathrm{~mm} ; 168 \mathrm{~h}-0.6 \mathrm{~mm} \quad 168 \mathrm{~h}-1-2 \mathrm{~mm}$ translucent, shiny, $0.4 \mathrm{~mm}$ shiny, $0.3 \mathrm{~mm}$

\section{Pseudomonas putida (E from Rubus ideaus)}

\begin{tabular}{l|llll}
$24-48 \mathrm{~h}$, yellow-green, & $24 \mathrm{~h}$, yellow to creamy, & $24 \mathrm{~h}$, creamy to white; & $24 \mathrm{~h}$ yellow to creamy; & $24 \mathrm{~h}$, white to creamy, \\
shiny, flat, round, fluorescent & shiny, translucent, & light shiny, flat, & $0.4 \mathrm{~mm} ;$ & $0.2 \mathrm{~mm} ;$ \\
under UV light, $2 \mathrm{~mm}$ & $0.4 \mathrm{~mm} ; 48 \mathrm{~h}-1 \mathrm{~mm}, 168$ & $0.2 \mathrm{~mm} ; 48 \mathrm{~h}-0.6 \mathrm{~mm}, 96 \mathrm{~h} 0.7 \mathrm{~mm}$ & $96 \mathrm{~h}-0.5 \mathrm{~mm}$ \\
& $\mathrm{~h}-2-2.5 \mathrm{~mm}$ & $\begin{array}{l}96 \mathrm{~h}-1-1.5 \mathrm{~mm}, \\
168 \mathrm{~h}-1.5-2 \mathrm{~mm}\end{array}$ & \\
\end{tabular}

\section{Serratia marcescens (from Alocasia)}

24 h, claret, lightly convex, shiny, $0.7 \mathrm{~mm} ; 96 \mathrm{~h} 1 \mathrm{~mm}$,

\section{$24 \mathrm{~h}$, red, lightly convex, shiny, $0.7 \mathrm{~mm}$;} $48 \mathrm{~h} 1 \mathrm{~mm}$
$24 \mathrm{~h}$, reddish-pink, lightly in the middle, lightly convex, shiny, $0.7 \mathrm{~mm}$
$24 \mathrm{~h}$, light red, lightly convex, shiny, $0.7 \mathrm{~mm}$; $48 \mathrm{~h} 1 \mathrm{~mm}$
24 h, red, lightly convex, shiny,

$0.7 \mathrm{~mm} ; 48 \mathrm{~h} 1 \mathrm{~mm}$

\section{Stenotrophomonas spp. (H from Rubus ideaus)}

\section{4 h, creamy, light flat,} shiny, $0.1 \mathrm{~mm}$; small inclusions in the medium. $168 \mathrm{~h} 1-1.2 \mathrm{~mm}$

$48 \mathrm{~h}$, yellow, round, in shape shiny, little convex, $0.5-1 \mathrm{~mm}$
24 h, creamy, light shiny, translucent, flat, $0.1 \mathrm{~mm}$; $96 \mathrm{~h} 0.5 \mathrm{~mm}$, $168 \mathrm{~h}-0.6 \mathrm{~mm}$
24 h, creamy-yellow, shiny, $0.1 \mathrm{~mm}$, $168 \mathrm{~h} 0.9 \mathrm{~mm}$
24 h, creamy, shiny, translucent, flat $0.1 \mathrm{~mm}$;

24 h, creamy, shiny, $96 \mathrm{~h} 0.3 \mathrm{~mm}, 168 \mathrm{~h} 0.6 \mathrm{~mm} \quad 0.1 \mathrm{~mm} ; 168 \mathrm{~h} 0.5 \mathrm{~mm}$

\section{Xanthomonas spp. (78 from Sambucus nigra)}

$48 \mathrm{~h}$, yellow, shiny, translucent, $0.2 \mathrm{~mm}$; $168 \mathrm{~h} 1-1.5 \mathrm{~mm}$
$48 \mathrm{~h}$, yellow, shiny, translucent, darker in the middle, $0.2 \mathrm{~mm}$; $168 \mathrm{~h} 1-1.5 \mathrm{~mm}$
$48 \mathrm{~h}$, yellow, shiny translucent, $0.2 \mathrm{~mm} ; 168$ h $0.5 \mathrm{~mm}$
$48 \mathrm{~h}$, dark yellow, $0.2 \mathrm{~mm}$; little slimy, 168

h $2 \mathrm{~mm}$

*Given is time (h) when colonies were recognizable and their diameter (mm); **growth under mineral oil. 
Table 3

The sensitivity of bacterial DNA detection by PCR depending on technique of DNA isolation and application of biological amplification (BIO-PCR)

\begin{tabular}{ccc}
\hline Bacteria & Method of DNA isolation & $\begin{array}{c}\text { Sensitivity of detection } \\
\text { (number of bacterial cells) }\end{array}$ \\
\hline Bacillus spp. (87) & Boiling & $1.5 \times 10^{5}$ \\
$1.5 \times 10^{7} \mathrm{w} 1 \mathrm{ml}$ & Boiling + BIO-PCR & $1.5 \times 10^{0}$ \\
& Genomic Mini & $1.5 \times 10^{2}$ \\
& Genomic Mini + BIO-PCR & $1.5 \times 10^{0}$ \\
Pseudomonas putida (E) & Boiling & $5 \times 10^{2}$ \\
$5 \times 10^{7} \mathrm{w} 1 \mathrm{ml}$ & Boiling + BIO-PCR & $5 \times 10^{0}$ \\
& Genomic Mini & $5 \times 10^{2}$ \\
Methylobacterium lusitanum (81b) & Genomic Mini + BIO-PCR & $5 \times 10^{0}$ \\
$3 \times 10^{6} \mathrm{w} 1 \mathrm{ml}$ & Boiling & $3 \times 10^{4}$ \\
& Boiling + BIO-PCR & $3 \times 10^{0}$ \\
\hline
\end{tabular}

Table 4

The number of bacterial cells detected in different segments per $1 \mathrm{mg}$ of multishoot tissue

\begin{tabular}{cccc}
\hline & \multicolumn{3}{c}{ Segment of multishoot } \\
\cline { 2 - 4 } Bacteria/plant & I (at the base) & II (middle part) & III (top) \\
\hline Bacillus spp. (87)/Anthurium andreanum & $1.67 \times 10^{5}$ & $3 \times 10^{4}$ & $1.33 \times 10^{3}$ \\
Pseudomonas putida (E)/Gerbera hybrida & $1.33 \times 10^{5}$ & $1 \times 10^{5}$ & $1.67 \times 10^{4}$ \\
Methylobacterium lusitanum (81b)/Sambucus nigra & $1 \times 10^{5}$ & $0.66 \times 10^{5}$ & $0.33 \times 10^{5}$ \\
\hline
\end{tabular}

\section{M $1 \overline{2} \overline{3} \overline{4} \overline{5} \overline{6} \overline{7} \overline{8} \overline{9} \overline{10} \overline{11} \overline{12} \overline{13} \overline{14}$}

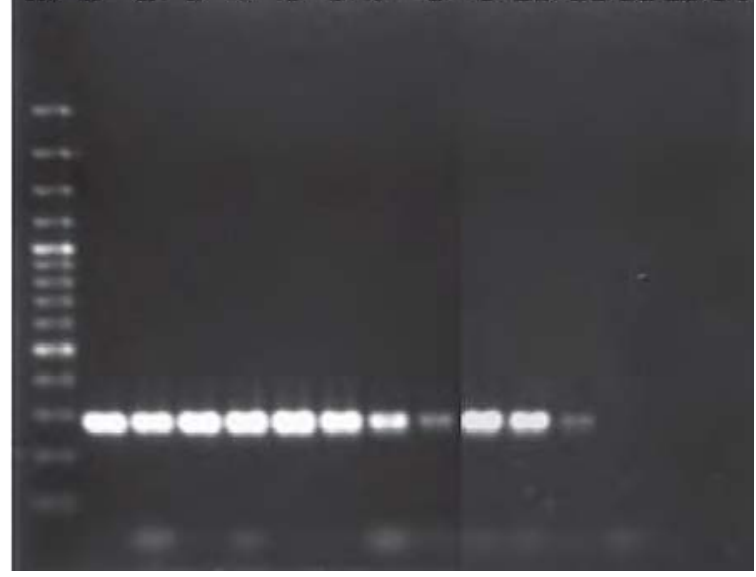

Fig. 5. Sensitivity of detection of Bacillus spp. strain 87 from tenfold dilutions of the bacterial DNA obtained by: Genomic Mini kit + BIO-PCR (lines 1-8) and by Boiling (lines 9-14): M - O'GeneRuler 100-3000bp (ThermoScientific, Life Science, Lithuania), $1-3 \times 10^{7}$, $2-3 \times 10^{6}, 3-3 \times 10^{5}, 4-3 \times 10^{4}, 5-1.5 \times 10^{3}, 6-1.5 \times 10^{2}$, $7-1.5 \times 10^{1}, 8-1.5 \times 10^{0}, 9-1.5 \times 10^{7}, 10-1.5 \times 10^{6}$, $11-1.5 \times 10^{5}, 12-1.5 \times 10^{4}, 13-1.5 \times 10^{3}, 14-1.5 \times 10^{2}$

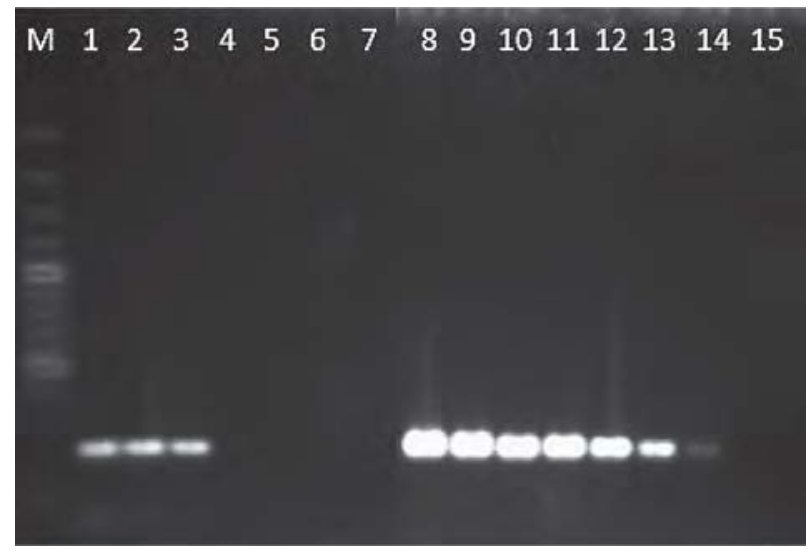

Fig. 6. Sensitivity of detection of Methylobacterium lusitanum strain $81 \mathrm{~b}$, from tenfold dilutions of the bacterial DNA obtained by: boiling (line 1-7) and by boiling + BIOPCR (lines 8-14): M - O'GeneRuler 100-3000bp (ThermoScientific, Life Science, Lithuania), $1-3 \times 10^{6}$, $2-3 \times 10^{5}, 3-3 \times 10^{4}, 4-3 \times 10^{3}, 5-3 \times 10^{2}, 6-3 \times 10^{1}$, $7-3 \times 10^{0}, 8-3 \times 10^{6}, 9-3 \times 10^{5}, 10-3 \times 10^{4}, 11-3 \times 10^{3}$, $12-3 \times 10^{2}, 13-3 \times 10^{1}, 14-3 \times 10^{0}, 15-$ negative control 


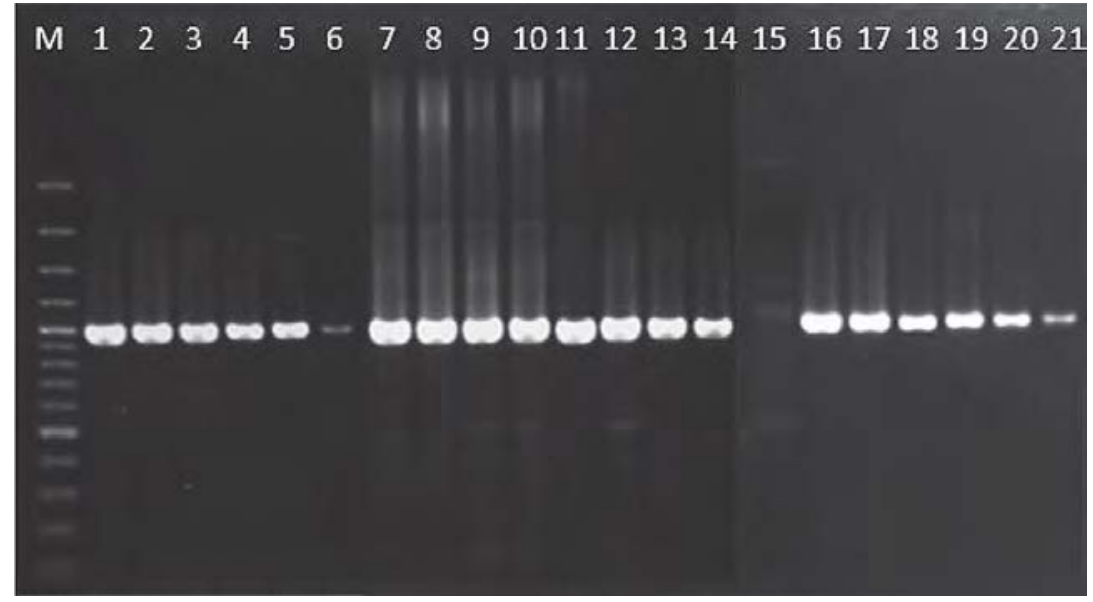

Fig. 7. Sensitivity of detection of Pseudomonas putida strain E from tenfold dilutions of the bacterial DNA obtained by: Genomic Mini kit (line 1-6), Genomic Mini kit + BIO-PCR (lines 7-14) and by boiling (lines 16-21): M - O'GeneRuler 100-3000bp (ThermoScientific, Life Science, Lithuania), $1-5 \times 10^{7}, 2-5 \times 10^{6}, 3-5 \times 10^{5}, 4-5 \times 10^{4}, 5-5 \times 10^{3}, 6-5 \times 10^{2}, 7-5 \times 10^{7}$, $8-5 \times 10^{6}, 9-5 \times 10^{5}, 10-5 \times 10^{4}, 11-5 \times 10^{3}, 12-5 \times 10^{2}, 13-5 \times 10^{1}, 14-5 \times 10^{0}, 15$ - O'GeneRuler 100-3000bp (ThermoScientific, Life Science, Lithuania), $16-5 \times 10^{7}, 17-5 \times 10^{6}, 18-5 \times 10^{5}, 19-5 \times 10^{4}, 20-5 \times 10^{3}, 21-5 \times 10^{2}$

The highly sensitive method for detection of bacteria in contaminated plant tissue cultures is very important especially at the initial stage when only a small number of bacteria can be present without visible symptoms both on/in explants and in/on media. Results of our study can suggest that detection of cultivable bacteria in washing liquid or plant fragment is more effective using microbiological method (streaking on bacteriological medium) than method based on PCR. A molecular detection of bacteria of known genus using PCR with the genus-specific primers confirmed that the BIO-PCR increased detection level of Bacillus spp. by $10^{2}-10^{5}$ times, Methylobacterium by $10^{2}-10^{4}$ times and Pseudomonas by $10^{2}$ times, depending on the DNA isolation method. Wang et al. [21] obtained similar results in detection of Xanthomonas albilineans, the pathogen of sugar cane, where BIO-PCR combined with the use of the half selective m-XAM medium was more sensitive than ELISA, DIA and PCR. BIO-PCR technique was most sensitive and reliable for Xanthomonas axonopodis pv. phaseoli and $P$. syringe pv. phaseolica detection $[22,23]$. $\mathrm{P}$ u ł a w ska and Sobiczewski [24] recommended this technique in detection of tumorigenic strains of Agrobacterium tumefaciens in soil and Erwinia amylovora in infected plants $[25,26]$. Sensitivity of detection in the above experiments was from 1 to 20 cells per $1 \mathrm{~g}$ or $1 \mathrm{ml}$ of a sample. These results suggest that instead of detection specific bacterial DNA, more effective are microbiological methods, including of plating of tissue washings on bacteriological media, because in the molecular method, detectability begins at app. 15 cells whereas on bacteriological medium, it is possible to detect a single bacterium. Moreover, searching for bacterial DNA could give false positive results by amplifying also DNA of bacteria, which do not survive disinfection.

In case of searching for specific bacteria using genus specific DNA primers in specimens of plant body, method of DNA extraction is important. The use Genomic Mini kit enables 10 times more sensitive bacteria detection than the extraction by boiling. However, in our study in case of Bacillus isolate the detection was possible only after pre-incubation, which could be related to presence of plant DNA polymerase inhibitors in Anthurium tissues and in shaking washings.

The use of primers universal for amplification of bacterial rDNA, recommended by $\mathrm{W}$ e i s b u rg et al. [17], which were applied in this work and in others [27] should be probably not advisable in cases of detection of bacterial DNA in a mixture with plant DNA because the primers amplify also fragments of chloroplast DNA [28]. In addition, this method detects all bacterial DNA, also those belonging to uncultivable bacteria and bacteriosomes. To exclude chloroplast DNA amplification other primers, e.g. according to $\mathrm{Ch}$ e $\mathrm{li}$ i s and Triplett [29] or B ulgari et al. [30], should be used to ensure that obtained PCR products are derived from bacterial templates. On the other hand, there is a question if a plant (in vitro explant) tissue could exist as free of bacteria [1].

\section{CONCLUSIONS}

1. The bacteriological media - King B, NBY, YDC, YNA, and YPGA enabled growth and morphological characterization of strains of 13 genera occurring as contaminants in plant tissue cultures, with the exception that Lactobacillus strain did not grow on KB medium, even under mineral oil. Only King 
B medium enabled the appearance of the characteristic traits as fluorescence of Pseudomonas or secretion of characteristic inclusions by Stenotrophomonas strains. Other strains studied could be not identified even in terms of genus. Pink color of slow growing colonies may eventually imply affiliation to pink Methylobacterium, claret color of fast growing ones to Serratia marcescens and yellow color to Xanthomonas or Flavobacterium.

2. The most suitable for visualisation of bacteria present in initial explants or in washings from in vitro explants at the initiation stage was 523 medium. The IM medium (1/2 MS salts with milk albumin $0.025 \%$ ) used routinely for initiation of plant tissue cultures can be useful for isolation of bacteria directly at culture initiation.

3. Medium K, recommended for Methylobacteriaceae, proved to be useless for the growth of Methylobacterium strain used in this study.

4. The BIO-PCR with genus-specific primers can be recommended for detecting/identifying single bacterial cells, but the procedure is extended by $2-5$ days.

5. At a low bacteria number population, more recommendable for detection of cultivable bacteria is the use of microbiological (placing of explants fragments or washing liquids on bacteriological medium) than molecular method based on DNA markers.

\section{Acknowledgements}

The authors thank Ms. Aleksandra Trzewik for help in molecular detection of bacteria in plant tissues. This work was supported by Ministry of Science and Higher Education as a research project No. 2 PO6A 02630

\section{Authors' contributions}

The following declarations about authors' contributions to the research have been made: concept of the study: TO; molecular identification and analyses: MK; microbiological identification: AM; consulting and managing of microbiological study: PS; plant cultures: MZ; providing Serratia marcescens for study: EZ; writing of the manuscript: TO, MK, PS.

\section{REFERENCES}

1. Holland MA, Polacco JC. PPFMs and other covert contaminants: is there more to plant physiology than just plant? Annu Rev Plant Physiol Plant Mol Biol. 1994; 45: 197-209. http://dx.doi.org/10.1146\%2Fannurev.arplant.45. 1.197

2. Orlikowska T, Zawadzka M. Bakterie w kulturach tkanek roślinnych in vitro/Bacteria in plant tissue culture.
Biotechnologia. 2006; 4(75): 64-77 (in Polish with English abstract).

3. Orlikowska T, Sobiczewski P, Zawadzka M, Zenkteler E. Kontrola i zwalczanie zakażeń i zanieczyszczeń bakteryjnych w kulturach roślinnych in vitrol The control and eradication of bacterial infections and contaminations in plant tissue culture. Biotechnologia. 2010; 2(89): 57-71 (in Polish with English abstract).

4. Leifert C, Ritchie JY, Waites WM. Contaminants of plant-tissue and cell cultures. World J Microbiol Biotechnol. 1991; 71: 452-469. http://dx.doi.org/10. $1007 \%$ 2FBF00303371

5. Leifert C, Waites WM, Nicholas JR. Bacterial contaminants of micropropagated plant cultures. J Appl Bacteriol. 1989; 67: 353-361. http://dx.doi.org/ 10.1111\%2Fj.1365-2672.1989.tb02505.x

6. Thomas P. In vitro decline in plant cultures: detection of a legion of covert bacteria as the cause for degeneration of long-term micropropagated triploid watermelon cultures. Plant Cell Tiss Organ Cult. 2004; 77: 173-179. http://dx.doi. org/10.1023\%2FB\%3ATICU.0000016824.09108.c8

7. Ivanova E, Doronina N, Trotsenko Y.Hansschlegelia plantiphila gen. nov. sp. nov., a new aerobic restricted facultative methylotrophic bacterium associated with plants. System Appl Microbiol. 2007; 30: 444-452. http://dx.doi.org/10.1016\%2Fj.syapm.2007.03.001

8. Reasoner DJ, Blannon JC, Geldreich EE. Rapid seven-hour fecal coliform test. Appl Environ Microbiol. 1979; 38: 229-236.

9. Viss PR, Brooks EM, Driver JA. A simplified method for the control of bacterial contamination in woody plant tissue culture. In Vitro Cell Dev Biol Plant 1991; 27P: 42. http://dx.doi.org/10.1007\%2FBF02632060

10. Murashige T, Skoog F. A revised medium for rapid growth and bioassays with tobacco tissue culture. Physiol Plant. 1962; 15:473-497.

11. Lloyd G, McCown B. Commercially-feasible micropropagation of mountain laurer, Kalmia latifolia, by use of shoot tip culture. Comb Proc Int Plant Propag Soc. 1980; 30: 421-427.

12. Lelli ot RA, Stead DE. Methods for the diagnosis of bacterial diseases of plants. Blackwell Scientific Pub. 1987; 216

13. Schaad NW, Jones JB, Chun W. Laboratory guide for identification of plant pathogenic bacteria. APS Press, $3^{\text {rd }}$ Ed., St. Paul, MN, USA; 2001.

14. Hansen BM, Leser TD, Hendriksen NB. Polymerase chain reaction assay for the detection of Bacillus cereus group cells. FEMS Microbiol. Lett. 2001; 202: 209-213. http://dx.doi.org/10.1016\%2FS0378-1097\%2801 $\% 2900309-3$

15. Nishio T, Yoshikura T, Itoh H. Detection of Methylobacterium species by $16 \mathrm{~S}$ rRNA gene-targeted PCR. Appl. Environm. Microbiol. 1997; 63: 1594-1597.

16. Widmer F, Seidler RJ., Gillevet PM, Watrud LS, Di Giovanni GD. A highly selective PCR protocol for detecting 16S rRNA genes of the genus 
Pseudomonas (Sensu Stricto) in environmental samples. Appl Environ Microbiol. 1998; 64: 2545-2553.

17. Weisburg WG, Barns SM, Pellettier DA, L a ne DJ.16S ribosomal DNA amplification for phylogenetic study. J Bacteriol. 1991; 173: 697-703.

18. Cassels AC, Tahmatsidou V. The influence of local plant growth conditions on non-fastidious bacterial contamination of meristem-tips of Hydrangea cultured in vitro. Plant Cell Tiss Organ Cult. 1996; 47: 15-26.

19. Pirttilä AM, Laukkanen H, Pospiech H, Myllylä R, Hohtola A. Detection of intracellular bacteria in the buds of schotch pine (Pinus sylvestris L.) by in situ hybridization. Appl Environm Microbiol. 2000; 66: 3073-3077. http://dx.doi.org/10.1128\%2FAEM.66.7. 3073-3077.2000

20. Norman DJ, Alvarez AM. Latent infections of in vitro anthurium caused by Xanthomonas campestris pv. dieffenbachiae. Plant Cell Tiss Organ Cult. 1994; 39: 55-61. http://dx.doi.org/10.1007\%2FBF00037592

21. Wang ZK, Comstock JC, Hatziloukas E, Schaad N.W. Comparison of PCR, BIO-PCR, DIA, ELISA and isolation on semiselective medium for detection of Xanthomonas albilineans, the causal agent of leaf scald of sugarcane Plant Pathol. 1999; 48: 245-252. http://dx.doi. org/10.1046\%2Fj.1365-3059.1999.00332.x

22. Akhavan M, Bahar G, Saeidi, Lak M. Comparison of different methods for detection of Xanthomonas axonopodis pv. phaseoli in bean seeds Iran. J Plant Path. 2009; 45: 1-3.

23. Schaad NW, Berthier-Schaad Y, Knorr D. A high throughput membrane BIO-PCR technique for ultra-sensitive detection of Pseudomonas syringae pv.phaseolicola. Plant Pathol. 2007; 56: 1-8. http://dx.doi.org/ 10.1111\%2Fj.1365-3059.2006.01488.x

24. Puławska J, Sobiczewski P. Detection of Erwinia amylovora in and on apple tissue using PCR. Acta Hortic. 2002; 590: 163-166.

25. López MM, Gorris MT, Llop P, Cubero J, Vicedo B, Cambra M. Selective enrichment improves isolation, serological and molecular detection of plant pathogenic bacteria. [In:] Dehne H.W., Adam G., Diekmann M., Frahm J., Mauler-Machnik A, van Halteren P. (eds). Diagnosis and identification of plant pathogens. Kluwer Academic Publishers, Dordrecht, The Netherlands; 1997. http://dx.doi.org/10.1007\%2F978-94-009-0043-1_25

26. Puławska J, Sobiczewski P. Development of a semi-nested PCR based method for sensitive detection of tumorigenic Agrobacterium in soil. J Appl Microbiol. 2005; 98: 710-721. http://dx.doi.org/10.1111\%2Fj.1365-26 72.2004.02503.x

27. Thomas P, Swarna GK, Patil P, Rawal RD. Ubiquitos presence of normally non-culturable endophytic bacteria in field shoot-tips of banana and their gradual activation to quiescent cultivable form in tissue culture. Plant Cell Tiss Organ Cult. 2008; 93: 39-54. http://dx.doi.org/10. 1007\%2Fs11240-008-9340-x

28. Ulrich K, Ulrich A, Ewald D. Diversity of endophytic bacterial communities in poplar grown under field conditions. FEMS Microbiol. Ecol. 2008; 63: 169-180. http://dx.doi.org/10.1111\%2Fj.1574-6941.2007.00419.x

29. Chelius MK, Triplett EW. The diversity of Archaea and Bacteria in association with the roots of Zea mays L. Microbial Ecology. 2001; 41: 252-263.

31. Bulgari D, Casati P, Brusetti L, Quaglino F, Brasca M, Daffonchio D, Bianco PA. Endophytic bacterial diversity in grapevine (Vitis vinifera L.) leaves described by 16S rRNA gene sequence analysis and length heterogenity-PCR. J Microbiol. 2009; 47: 393-401. http://dx.doi.org/10.1007\%2Fs12275-009-0082-1

\section{Izolacja, wstępna charakterystyka i wykrywanie bakterii zanieczyszczających kultury roślinne in vitro}

\section{Streszczenie}

W pracy określono możliwość wykrywania obecności bakterii najczęściej spotykanych w kulturach roślinnych in vitro, należących do różnych rodzajów, przy pomocy technik mikrobiologicznej i molekularnej. Za najbardziej przydatną do izolacji uznano pożywkę 523 a także pożywkę zawierającą $1 / 2$ soli mineralnych MS stosowaną do inicjacji kultur roślinnych, z dodatkiem 0,025\% albuminy mlecznej. Większą czułość wykrywania bakterii przy pomocy markerowego DNA uzyskano przy zastosowaniu techniki polegającej na preinkubacji badanego materiału na pożywkach bakteriologicznych, a następnie na izolacji DNA ze wzrostu (BIO-PCR). Przy porównaniu sposobów izolacji DNA większą czułość uzyskano stosując zestaw Genomic Mini (A\&A Biotechnology) niż po zastosowaniu ekstrakcji w temperaturze wrzenia.

Handling Editor: Elżbieta Weryszko-Chmielewska

This is an Open Access digital version of the article distributed under the terms of the Creative Commons Attribution 3.0 License (creativecommons.org/licenses/by/3.0/), which permits redistribution, commercial and non-commercial, provided that the article is properly cited.

CThe Author(s) 2013 Published by Polish Botanical Society 